\title{
Proliferation of differentiated glial cells in the brain stem
}

P.C. Barradas ${ }^{1,2}$ and L.A. Cavalcante ${ }^{2}$

\author{
1Departamento de Farmacologia e Psicobiologia, Instituto de Biologia, \\ Universidade do Estado do Rio de Janeiro, Rio de Janeiro, RJ, Brasil \\ 2Programa de Neurobiologia, Instituto de Biofísica Carlos Chagas Filho, \\ Universidade Federal do Rio de Janeiro, Rio de Janeiro, RJ, Brasil
}

\begin{abstract}
Correspondence

P.C. Barradas

Departamento de Farmacologia e

Psicobiologia

Instituto de Biologia, UERJ

Av. 28 de setembro

$87 \mathrm{fds}, 5^{\circ}$ andar

20551-030 Rio de Janeiro, RJ

Brasil

Fax: 55 (021) 280-8193

E-mail:pcrisbar@omega.Incc.br

Presented at the 5 th International Symposium on Radioautography, São Paulo, SP, Brasil,

August 24-26, 1997.

Research supported by FAPERJ, SR2/UERJ, CNPq and CEPG/UFRJ

....................

Received September 5, 1997 Accepted September 23, 1997

Classical studies of macroglial proliferation in muride rodents have provided conflicting evidence concerning the proliferating capabilities of oligodendrocytes and microglia. Furthermore, little information has been obtained in other mammalian orders and very little is known about glial cell proliferation and differentiation in the subclass Metatheria although valuable knowledge may be obtained from the protracted period of central nervous system maturation in these forms. Thus, we have studied the proliferative capacity of phenotypically identified brain stem oligodendrocytes by tritiated thymidine radioautography and have compared it with known features of oligodendroglial differentiation as well as with proliferation of microglia in the opossum Didelphis marsupialis. We have detected a previously undescribed ephemeral, regionally heterogeneous proliferation of oligodendrocytes expressing the actin-binding, ensheathment-related protein 2'3'-cyclic nucleotide 3'-phosphodiesterase (CNPase), that is not necessarily related to the known regional and temporal heterogeneity of expression of CNPase in cell bodies. On the other hand, proliferation of microglia tagged by the binding of Griffonia simplicifolia B4 isolectin, which recognizes an alpha-D-galactosyl-bearing glycoprotein of the plasma membrane of macrophages/microglia, is known to be long lasting, showing no regional heterogeneity and being found amongst both ameboid and differentiated ramified cells, although at different rates. The functional significance of the proliferative behavior of these differentiated cells is unknown but may provide a lowgrade cell renewal in the normal brain and may be augmented under pathological conditions.
\end{abstract}

\section{Introduction}

Classical studies of the genesis of macroglial cells in the cerebral white matter and forebrain tracts have suggested that their main source in developing and adult animals is the subventricular zone (SVZ) lining the walls of the cerebral ventricles (1-5). Much less attention has been devoted to the identi-
Key words

- $\left[{ }^{3} \mathrm{H}\right]$-Thymidine radioautography

- Oligodendroglial proliferation

- 2'3'-Cyclic nucleotide 3'-phosphodiesterase

- Microglial proliferation

- Lectin

- Marsupial 
and Kishi and coworkers (10), later confirmed and extended by Luskin (11) and by Lois and Alvarez-Buylla (12), indicated that the rostral telencephalic SVZ is a source of olfactory interneurons rather than of glial cells (but see Ref. 9) in developing and adult animals. It is still unclear whether this emigration is the only or even the main alternative explanation for findings obtained by cumulative tritiated thymidine $\left(\left[{ }^{3} \mathrm{H}\right]-\mathrm{T}\right)$ labeling and clonal determination suggesting that one of each pair of postmitotic cells in the SVZ is destined to die whereas the other cell continues to proliferate in a stem cell mode without ever migrating away from this zone (13). Finally, interest in in situ glial proliferation has benefited from the findings of nuclear proteins such as statin which is specific for quiescent noncycling cells and for senescent nondividing cells (14), and cyclin which is specific for cycling cells (15). Statin is absent from cells in parts of the telencephalic SVZ known to have maximal proliferative capacity as well as from as many as one third of the cells in telencephalic tracts in the adult rodent brain (16).

The modest extent of the SVZ in the brain stem, particularly at its rostral level, increases the interest in the general problem of whether in situ proliferation of postmigratory macroglial cells is of great importance therein both in infant and young adult animals. In this review, we consider the evidence for a low-rate production of oligodendrocytes and microglial cells in the brain stem of the developing opossum Didelphis marsupialis. This species has been chosen in view of the superior temporal resolution of developmental events that can be gained from its protracted period of neural development (17) and the available information on glial cell differentiation in the superior colliculus and, to a lesser extent, in other brain stem structures (17-22). The opossum is born after a 13-day gestation period and undergoes a large part of neural development, including neurogenesis of the retina and sev- eral brain stem structures $(7,23)$, during the two and half months it remains secluded in the maternal pouch. Eye opening occurs by the 67 th postnatal day $(\mathrm{P})$, corresponding to a coecal period (conception to eye opening; see Ref. 24) of 80 days. Only after eye opening there occurs the release of the maternal nipple from the pups' mouth and their emergence from the pouch (mode: 72 nd postnatal day). Weaning occurs by the 82 nd postnatal day (25), signaling the end of a "developmental period" recently proposed for all mammals by Ashwell et al. (26).

The proliferation of ameboid and ramified microglia is also briefly reviewed here (see also Ref. 22) although these cells appear not to be derived from the neuroepithelium. However, there is recent evidence that many cells immunoreactive for the GD3 ganglioside, formerly presumed to be oligodendrocyte precursors $(27,28)$, are, in fact, microglia (29) and that both oligodendrocytes and ameboid microglia may express carbonic anhydrase II $(30,31)$.

\section{Markers of cell proliferation}

Some distinct labeling methods may be used to identify and locate proliferating cells. First, classical radioautographic techniques are used to label dividing cells that had incorporated and retained $\left[{ }^{3} \mathrm{H}\right]-\mathrm{T}$ in their replicating DNA during the $S$ phase of the cell cycle $(4,5,32)$. Markers of the $S$ phase include bromo-deoxyuridine (BrdU), which is also incorporated and retained in DNA and revealed by immunohistochemistry (33). Second, immunohistochemical detection of the proliferating cell nuclear antigen (PCNA/ cyclin), a $36-\mathrm{kDa}$ auxiliary protein of DNA polymerase- $\delta$, allows labeling of the enzyme complex responsible for leading-strand synthesis during DNA replication $(34,35)$. PCNA is tightly associated with DNA replication sites in the cell nucleus and is found at peak levels during the "synthesis", or S phase, of the cell cycle, with moderate immunodetect- 
able levels also being present in late $\mathrm{G} 1$ and early G2 phases of the cell cycle (15). Finally, staining the minor groove of DNA with the fluorescent nucleic acid stain Hoechst 33342 (bisbenzimide) allows visualization of chromosomal structure (36). This provides much easier identification of cells with condensed chromatin in mitosis than could be obtained by routine histological stainings. However, in view of the short duration of mitosis in comparison with the entire cell cycle, the non-visualization of chromatin condensation is a poor indication of the absence of proliferative capacity. The absence of this capacity could only be ascertained by the expression of non-proliferation-dependent nuclear proteins such as statin (16).

Preference for a given labeling method for the determination of proliferative status depends on many factors. It has been suggested that BrdU may impair differentiation in the muscle by stifling the expression of the myo Dl gene (37) but there was no evidence for pyknosis or interference with the ability of neurons to migrate and differentiate after repeated exposure to $\mathrm{BrdU}$ (38). With regard to $\left[{ }^{3} \mathrm{H}\right]-\mathrm{T}$, it has been reported that ionizing radiation may block proliferation (39) but that has not been confirmed in studies of chronic exposure to $\left[{ }^{3} \mathrm{H}\right]-\mathrm{T}$ from embryonic day 9 to birth in rats (40). In addition to these effects, it has been suggested that significant differences can be observed in the numerical density of labeled cells in comparisons be- tween a marker characteristic of the $\mathrm{S}$ phase (e.g., $\left[{ }^{3} \mathrm{H}\right]-\mathrm{T}$ ) and one associated with the $\mathrm{S}$ plus G1 and G2 phases (PCNA; 41). However, a bias in favor of PCNA may be negligible or non-existent provided that extremely short periods of survival (less than $2 \mathrm{~h}$ ) after $\left[{ }^{3} \mathrm{H}\right]-\mathrm{T}$ are avoided. For instance, we have found no major differences between adjacent PCNA immunohistochemical and $\left[{ }^{3} \mathrm{H}\right]-$ T radioautographic sections of the brain stem of pouch young opossums $2 \mathrm{~h}$ after a single injection of $\left[{ }^{3} \mathrm{H}\right]-\mathrm{T}$ (Figure 1). Thus, we have chosen to employ $\left[{ }^{3} \mathrm{H}\right]-\mathrm{T}$ radioautography not only due to its simplicity and reliability but also to avoid the masking by another immunohistochemical reaction of light 2'3' cyclic nucleotide 3'-phosphodiesterase (CNPase) reactivity in some oligodendrocytes.

Another consideration that should be kept in mind is the possibility of studying the temporal relationship between proliferation and phenotypic expression such as can be inferred by varying the interval from the administration of an exogenous marker $\left(\left[{ }^{3} \mathrm{H}\right]-\right.$ T or BrdU) to sacrifice of the animal (see the section "Proliferation of differentiating oligodendroglia and microglia in the opossum brain stem").

\section{Phenotypic markers of oligodendroglia and microglia}

After the first studies that identified the "third element" of the central nervous sys-
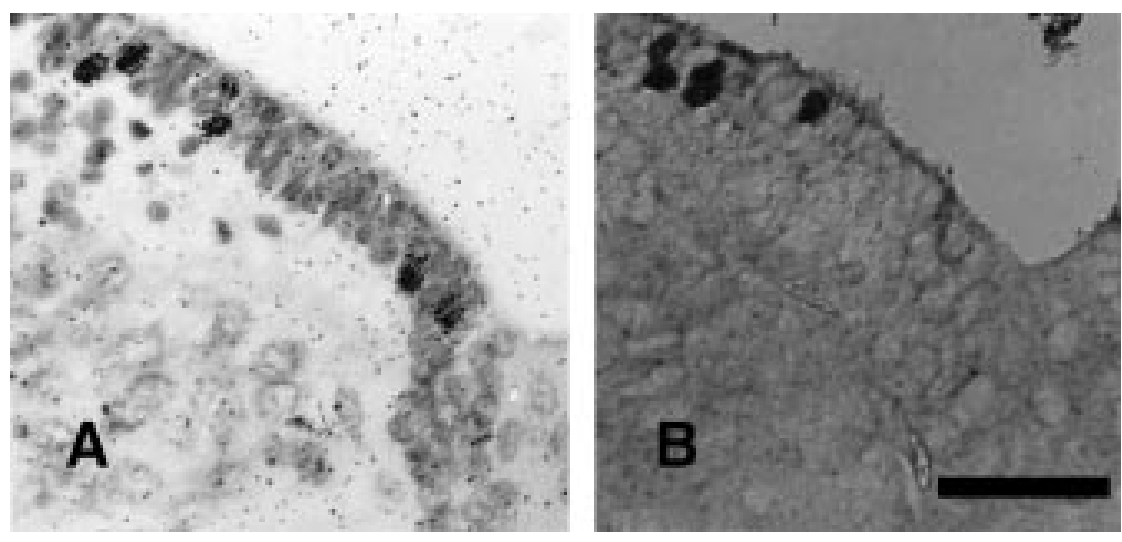

Figure 1 - A comparison of the identification of proliferating cells by $\left[{ }^{3} \mathrm{H}\right]-\mathrm{T}$ radioautography and by proliferating cell nuclear antigen (PCNA) immunohistochemistry. Photomicrographs of $10-\mu \mathrm{m}$ adjacent coronal sections passing through the fourth ventricle (IVv) of an opossum aged 12 postnatal days (P12), that was killed $2 \mathrm{~h}$ after a single intraperitoneal injection of $\left[{ }^{3} \mathrm{H}\right]-\mathrm{T}(10 \mu \mathrm{Ci} / \mathrm{g}$ body weight). A, Dipping radioautogram obtained with Kodak NTB2 emulsion and counterstained with cresyl-violet. Observe cells containing silver grains in the ventricular/ subventricular zone of the IVv. $B$, Immunoreaction with an anti-PCNA monoclonal antibody (Sigma) using the biotin-avidin-horseradish peroxidase method (Sigma kit). Magnification bar $=50 \mu \mathrm{m}$. 
tem after neurons (the first element) and astrocytes (the second element), at the end of the last century, the use of silver carbonate impregnation by del Rio Hortega (42) showed that, in fact, this third element included two distinct cell types - oligodendrocytes and microglia, derived from the neuroectoderm and the mesoderm, respectively. Morphological criteria established from silver carbonate preparations by light and electron microscopy remained as the only tool for the identification of these cell types until the late 1970's, when histochemical and immunohistochemical markers were described $(43,44)$. These markers allowed the investigation of several aspects of oligodendroglial and microglial biology in terms of their differentiation, interactions with other neural cells or responses to pathological challenges.

There is no agreement with regard to the precocity of expression of immunohistochemical markers of oligodendroglia. However, precocious markers are those expressed by proliferating cells or, at least, by cells that have withdrawn recently from the mitotic cycle, whereas late markers are those expressed at the final stage of myelination, i.e., at the time of myelin compaction. Among those considered as precocious markers are sulfatides, the main antigen recognized by the $\mathrm{O} 4$ antibody $(45,46)$, carbonic anhydrase II ( 27,30 but see 31$)$, the antigens recognized by the monoclonal antibody Rip ( $23 \mathrm{kDa}$ and $160 \mathrm{kDa}$ molecular mass) $(47,48)$ and CNPase (20,49-51).

CNPase links myelin-related proteins to the cytoskeleton $(52,53)$ and appears to interact with membrane lipids during extension of the oligodendroglial process (54). A single CNPase gene encodes two isoforms, CNPase I (46 kDa) and CNPase II (48 kDa), which are differentially regulated during development, with the larger protein being expressed earlier than CNPase I (55).

There is also recent evidence for early, selective location of 2 precocious oligodendroglial markers: the mRNAs for the $\alpha$ re- ceptor of the platelet-derived growth factor $(56,57)$ and for DM-20, a product of the alternative splicing of the proteolipid protein (PLP) gene (58).

The markers expressed later in the course of oligodendroglial differentiation include galactocerebroside (GC) that appears in postmitotic oligodendrocytes (59), myelin basic protein (MBP) that appears at the time of axon ensheathment (44), and PLP and myelin-associated glycoprotein that appear during early stages of myelin sheath formation (60). In addition, two other myelin proteins related to later stages of oligodendroglial differentiation and to the myelin compaction phase have been described: the myelin oligodendrocyte glycoprotein (61) and the myelin-associated/oligodendrocytic basic protein (62). Many of these markers such as GC and MBP are phylogenetically conserved, at least as far as higher vertebrates are concerned. The main exception concerns $\mathrm{S} 100$ which is characteristic of astrocytes in the mammalian brain and of oligodendrocytes in the avian brain $(63,64)$.

The classification of precocious and late oligodendroglial markers is, however, relatively uncertain. For instance, there is some degree of uncertainty with respect to the specificity of antibodies that presumably recognize only sulfatide or only GC (65). Furthermore, a study of the proliferative capacity and expression of oligodendroglial markers in cerebral cortex concluded that the lipid antigens recognized by the $\mathrm{O} 4$ antibody (mostly sulfatide) were expressed by proliferating cells but these same cells did not express PLP or CNPase (66). Surprisingly, a minor number of proliferating cells expressed MBP.

In analogy to oligodendrocytes, the introduction of selective and reproducible methods such as histoenzymatic techniques and methods relying on the binding of antibodies or lectins to microglia were of paramount importance for studies of the differentiation and physiopathological role of this cell type. 
The histoenzymatic methods for nucleoside diphosphatase and thiamine pyrophosphatase were among the first to be introduced and still are particularly useful because of their applicability to mammals $(67,68)$, birds $(69)$ and reptiles (70). Mutatis mutandis, this is also the case for some lectins such as those obtained from Griffonia simplicifolia and Lycopersicon esculentum (tomato) (22,7173) which are effective for both ameboid and ramified microglia in several species of mammals. In addition, antibodies recognizing microglial cells have been found effective for a given species, including fish (74), amphibian (75), mouse (76) and other rodents (77-80), humans (81) and the quail (82).

Two highly species-specific antibodies, F4/80 - which recognizes a 160-kDa plasma membrane glycoprotein specific of mouse macrophages (83) - and QH1 - which recognizes endothelial and hemopoietic cells in the quail (84) - label all stages of development of microglia $(76,82)$. In the particular case of QH1, it has been shown that nonendothelial cells of hemangioblastic lineage appear in the avian nervous system at very early developmental stages (85), with additional microglial precursors entering the brain tissue at later stages through specific points on the pial surface (86) and entering the retina from the pecten (87). The entrance of precursors into the brain tissue very early in development may provide a partial explanation for the appearance of macrophages and ameboid microglia in dissociated cell cultures of embryonic brain tissue that has not yet been vascularized (88).

Irrespective of the interpretations of microglial lineage based on labeling with antibodies common to microglia and hemopoietic cells (e.g., 76,82) vs microglia and a particular type of neuroglia (88), stable markers such as F4/80 and QH1 antibodies and isolectin BS1/B4 of G. simplicifolia are particularly useful for other studies such as those aiming to compare the proliferative capacity of ameboid and ramified microglia.

\section{Proliferation of differentiating oligodendroglia and microglia in the opossum brain stem}

The proliferation of macroglial cells has been addressed by $\left[{ }^{3} \mathrm{H}\right]-\mathrm{T}$ radioautography with a fair amount of success for astroglial cells in several rat brain regions including the midbrain (for a review, see Ref. 32). However, there has been much less agreement on the proliferative capability of oligodendrocytes. Thus, there is no ultrastructural evidence for division of oligodendroglia during myelin formation in the spinal cord (89) whereas there is evidence for the optic nerve and the anterior commissure $(90,91)$. A recent report suggests that the proportion of statin-negative cells within brain fiber tracts is about one third of total cells (16), thus being higher than the one-fifth of nonoligodendrocytic cells (92).

As previously described (21), expression of CNPase starts in the medial longitudinal fascicle at P17. Findings on the onset, peak and disappearance of CNPase expression from cell bodies and on the appearance and augmentation in fiber sheaths in the brain stem are summarized in Table 1 . We have attempted to express the duration of CNPase immunoreactivity in cell somata (from the midpoint of time of onset to the midpoint of time of loss; see Table 1) as a fraction of the duration of the "developmental period" (108 days), defined as the time from conception to weaning (26), for eventual comparison with other mammals.

The onset of CNPase expression in the medial longitudinal fascicle (P17) coincides with the detection of $\left[{ }^{3} \mathrm{H}\right]-\mathrm{T}+$ cells within fiber tracts in short survival animals, suggesting the occurrence of proliferation of glial cells or their precursors. These cells show no CNPase immunoreactivity and may be considered macroglial precursors on the basis of their cytological features such as 
Table 1 - CNPase expression in the opossum brain stem.

${ }^{*}$ The first postnatal $(\mathrm{P})$ day of the range referring to onset in (loss from) cell bodies indicates that CNPase immunoreactivity was still not detected (still detected). \% d.p.: Percent of developmental period (conception to weaning $=95$ days). (Partially reproduced from Ref. 21 ; courtesy of Rapid Communications of Oxford Ltd.)

\begin{tabular}{|c|c|c|c|}
\hline Tract/white matter & $\begin{array}{l}\text { set in cell bodies } \\
\qquad(P)^{*}\end{array}$ & $\begin{array}{l}\text { Loss from cell bodies } \\
\qquad(P)^{*}\end{array}$ & $\begin{array}{l}\text { Duration in cell bodies } \\
\text { (\% d.p.) }\end{array}$ \\
\hline \multicolumn{4}{|l|}{ Medial longitudinal fascicle } \\
\hline Rostral level & $15-17$ & $25-27$ & 10 \\
\hline Caudal level & $20-22$ & $30-32$ & 10 \\
\hline Root of VIII nerve & $22-25$ & $>40$ & $>17$ \\
\hline Trigeminal spinal tract & $22-25$ & $>40$ & $>17$ \\
\hline Lateral lemniscus (medullary-pontine traject) & $25-27$ & $>40$ & $>15$ \\
\hline Tegmental pontine-midbrain transition & $25-27$ & $>80$ & $>57$ \\
\hline Medial lemniscus (medullary-pontine traject) & $32-35$ & $>40$ & $>7$ \\
\hline Midbrain tegmentum & 33-35 & $>80$ & $>49$ \\
\hline Inferior colliculus & $37-40$ & $>80$ & $>43$ \\
\hline \multicolumn{4}{|l|}{ Superior colliculus } \\
\hline Deep layers & $45-46$ & $>80$ & $>36$ \\
\hline Optic layer & $46-50$ & $50-57$ & 6 \\
\hline
\end{tabular}

large nuclei (92). Tritium-labeled cells also continue to appear in the brain stem VZ/SVZ from P17 to P22 and, as judged from the cessation of midbrain neurogenesis at this stage (7), are likely to be glial precursors. No evidence for CNPase immunoreactivity has been found in the VZ/SVZ at either the aqueduct or IV ventricle level.

At P25-P27, there is an abrupt increase of CNPase+ cells in lower brain stem tracts (Table 1) and the ephemeral occurrence of CNPase+ cells in the respective VZ/SVZ with an occasional cell apparently in mitosis (Figure 2). At the same time, the number of

Figure 2 - Expression of a precocious oligodendroglial marker (CNPase) in germinative zones of the opossum brain stem. Photomicrograph of a parasagittal section passing through the IVv in a P27 animal. Immunoreaction with an anti-CNPase polyclonal antibody using the biotinavidin-HRP method (Sigma kit). CNPase+ cells at the margins of IVv (thin arrows). Note that the immunoreactive profile pointed at by the thicker arrow seems to be a cell in telophase. Magnification bar $=25 \mu \mathrm{m}$.

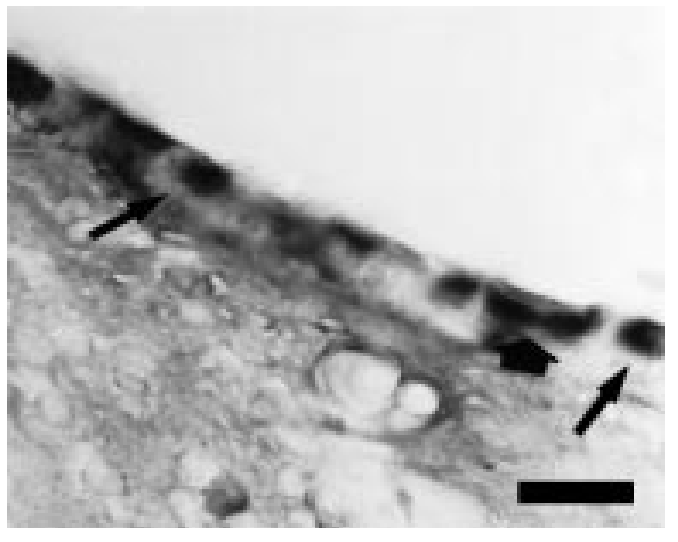

$\left[{ }^{3} \mathrm{H}\right]$-T-labeled cells in VZ/SVZ was reduced substantially with respect to previous stages in parallel with the beginning of the peak period (P25-P35) for interfascicular $\left[{ }^{3} \mathrm{H}\right]-\mathrm{T}+$ cells at short survivals after injection (Table 2). A sparse number of these cells, found in the medial longitudinal fascicle, trigeminal spinal tract and lateral lemniscus, are doublelabeled elements $\left(\mathrm{CNPase}+/\left[{ }^{3} \mathrm{H}\right]-\mathrm{T}+\right)$ (Figure 3, Table 2).

The results for the lower brain stem stand in marked contrast to those obtained for the midbrain in which double-labeled cells were never found with short survivals after $\left[{ }^{3} \mathrm{H}\right]-\mathrm{T}$ injections (compare midbrain tegmentum and inferior colliculus in Table 1 with the occurrence of double-labeled cells in Table 2). This result indicates that, in addition to the heterogeneity in CNPase expression that we have previously described (21), there may also be regional heterogeneities in the proliferation capacity of CNPase-expressing cells. This in situ proliferative diversity is particularly striking since it is independent of the duration of CNPase expression which is relatively short-lived in the medial longitudinal fascicle and long lasting in the midbrain 
Table 2 - Summary of the distribution of $\left[{ }^{3} \mathrm{H}\right]-\mathrm{T}+$ cells after short or long survivals and CNPase + cells in the opossum brain stem.

See also Table 1 that summarizes the onset and duration of CNPase expression in cell bodies of oligodendrocytes in representative tracts and nerve roots in the brain stem. *: [3H]-T+ cells; \#: CNPase+ cells; */\#: doublelabeled cells. Two symbols indicate larger average numbers for the entire brain stem.

\begin{tabular}{l|l|l|l|l|l|l|l|l|l|l|l|l|l}
\hline \\
$\begin{array}{l}\text { Age at } \\
\text { injection }\end{array}$
\end{tabular}
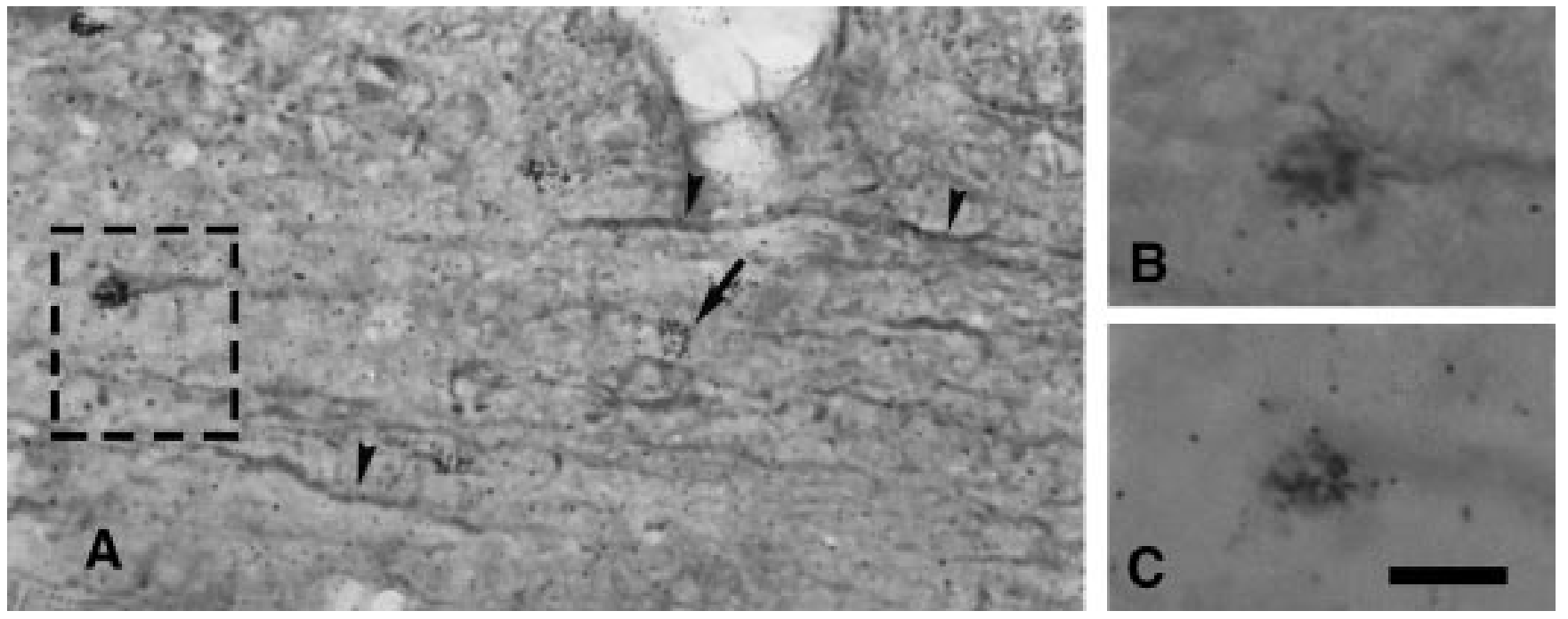

Figure 3 - Proliferation of interfascicular, CNPase+ and CNPase- cells. Parasagittal section through the medial longitudinal fascicle containing the ponsmedulla transition in a P27 opossum that received a single intraperitoneal $\left[{ }^{3} \mathrm{H}\right]-\mathrm{T}$ injection $(10 \mu \mathrm{Ci} / \mathrm{g}$ body weight) and was killed $2 \mathrm{~h}$ later. Immunoreaction with an anti-CNPase polyclonal antibody using the biotin-avidin-HRP method (Sigma kit) followed by radioautography as in Figure 1A. $A$, Panoramic view to show CNPase+ fiber sheaths (arrowheads) with interspersed radiolabeled $\left[{ }^{3} \mathrm{H}\right]-\mathrm{T}+$ cells, one of which is within a box of interrupted lines and shown at higher magnification and at two focal depths in $B$ and $C$. The arrow points at a CNPase-/[3 H]-T+ cell. $B, B o x e d$ area in $A$ with focus on the immunohistochemical product. $C$, The same area with focus on the silver grains. Magnification bar: $A=25 \mu \mathrm{m} ; \mathrm{B}$ and $\mathrm{C}=10 \mu \mathrm{m}$. 
tegmentum, inferior colliculus and deep layers of the superior colliculus. This fact suggests that the absence of double-labeled cells in the superior colliculus optic layer in short survival animals may not be artifactual, i.e., due to the short duration of CNPase expression in this layer (Table 1). It is interesting to note that the midbrain is devoid of early precursors expressing DM-20 mRNA whereas these precursors are numerous in the lower brain stem of the mouse (58).

In spite of the similar pattern of CNPase expression and similar lack of double-labeled cells in short survival animals, the midbrain tegmentum and the inferior colliculus may acquire oligodendrocytes according to different patterns of proliferation, incoming migration or both. In animals surviving one week or more after $\left[{ }^{3} \mathrm{H}\right]$-T injection, a large number of double-labeled cells are found in the midbrain tegmentum but not in the inferior colliculus. Interestingly, CNPase+ oligodendrocytes with variable numbers of radioautographic silver grains were often found in the same microscopic field with the longer survival, indicating that the oligodendroglial precursors passed through a variable number of cell cycles before CNPase expression (Figure 4). Further work is necessary to ascertain whether the lack of doublelabeled cells in the inferior colliculus arises simply from dilution of the label by additional cell cycles. It should be noted that the superior colliculus also lacks double-labeled cells in animals surviving for hours or days after $\left[{ }^{3} \mathrm{H}\right]-\mathrm{T}$ injection. However, the short duration of CNPase expression in the optic layer cell bodies poses additional problems for the interpretation of these results.

Regional differences in the proliferative ability of cells that have differentiated to the point of expressing the ensheathing-related protein CNPase might explain apparent conflicts about the issue of oligodendrocyte proliferation referred to previously (see Introduction). Such regional heterogeneities might be connected to both the restricted regional distribution of early precursors (58) and to differences in the responsiveness of oligodendroglial proliferative stages to mitogenic
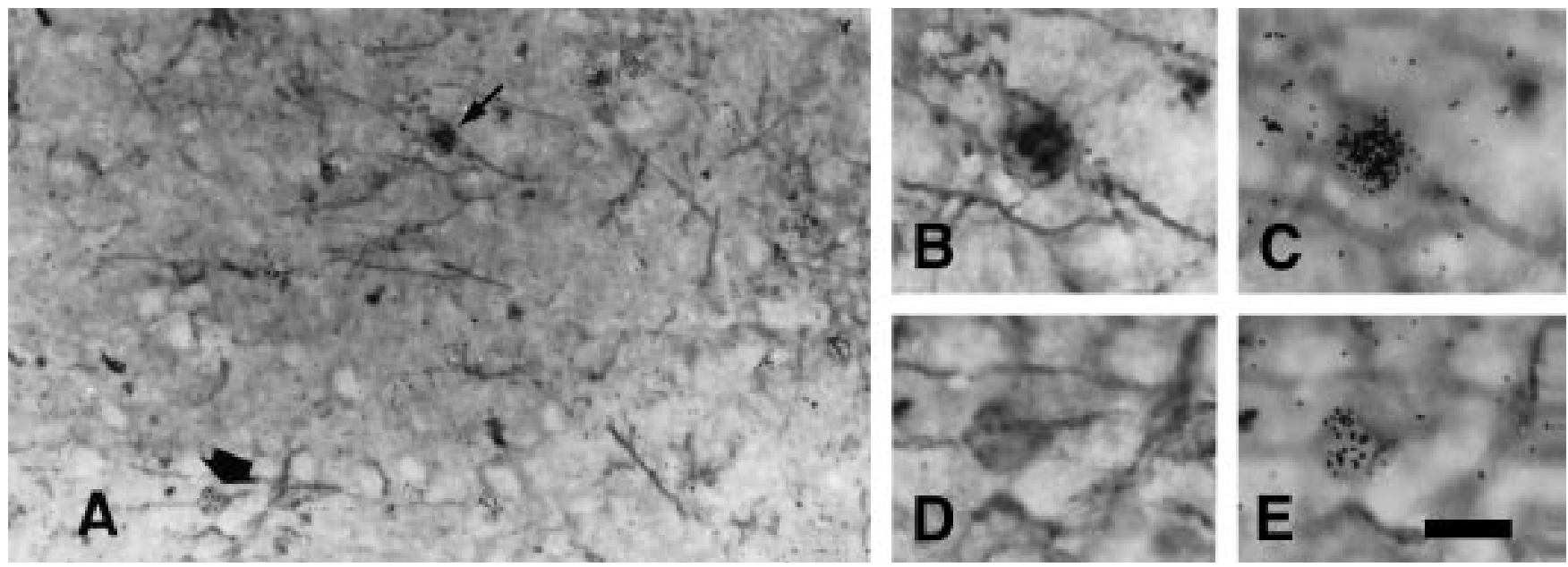

Figure 4 - Differentiation of oligodendroglia in the rostral brain stem. Photomicrographs of a coronal section passing through the midbrain tegmentum in a P37 opossum that received a single intraperitoneal $\left[{ }^{3} \mathrm{H}\right]-\mathrm{T}$ injection $(10 \mu \mathrm{Ci} / \mathrm{g}$ body weight) at P25. After the immunoreaction with the anti-CNPase antibody, the sections were submitted to the radioautographic procedure. A, Low power view of a field showing many CNPase+cells and nerve fibers. The arrows point to some of the CNPase+ oligodendrocytes that also show radioautographic silver grains, with the cells indicated by a thin and a thick arrow shown at higher magnifications in $\mathrm{B} / \mathrm{C}$ and $\mathrm{D} / \mathrm{E}$, respectively. $B$ and $D$, Focus on the CNPase reaction product; $C$ and $E$, focus on the silver grains. Note that the oligodendrocyte in $\mathrm{B} / \mathrm{C}$ has a large number of silver grains, suggesting that it has stopped proliferating soon after $\left[{ }^{3} \mathrm{H}\right]-\mathrm{T}$ uptake. On the other hand, the cell in D/E, with a smaller number of silver grains, may have passed through several cell cycles between [ $\left.{ }^{3} \mathrm{H}\right]-\mathrm{T}$ uptake and the onset of CNPase expression at P35-37. Magnification bar: $A=50 \mu \mathrm{m} ; \mathrm{B}-\mathrm{E}=10 \mu \mathrm{m}$. 
control (93). There is convincing evidence from the distribution of DM-20 mRNA (58) and the capacity of divisions of the early embryonic brain to generate oligodendrocytes in culture (94) that the midbrain lacks early oligodendroglial precursors and has to acquire oligodendroglia of undefined stages by immigration. It has been assumed that the source of this oligodendroglia is the DM-20 mRNA+ basolateral diencephalic plate (58) but there are no compelling reasons to rule out a myelencephalic origin or even separate origins for tegmental and tectal oligodendroglia. It is possible that differences in origin and/or in the migration route might result in regionally different distribution of proliferative stages of the oligodendrocyte lineage that may or may not be responsive to mitogenic influences by non-neuronal cells such as stages defined in vitro by Gard and Pfeiffer (93). Differences in the abundance of nonoligodendroglial non-neuronal cells in large regions such as the telencephalon may cause oligodendroglia to differ even between related portions of white matter, with CNPase+ cells being non-proliferative in the internal capsule $(66,95)$ and proliferative in the cortical white matter (95).

Our interest in the differentiation and proliferation of microglial cells was, in fact, stimulated by the ventrodorsal gradient of myelination demonstrable in the superior colliculus (19) and its discrepancy with respect to the gradient observed for astrocytes (18). However, detailed information is not available for other brain stem regions although it has been observed that colonization of the midbrain tectum by microglial cells starts later than in the pons and medulla. It should also be remarked that features of microglial proliferation are rather similar throughout the brain stem.

Acquisition of microglia, recognized by labeling with the Griffonia simplicifolia B4 isolectin, occurs far in advance (by about one month) of the appearance of CNPase immunoreactivity, although predicting the direction of the gradients of both CNPase expression and overt myelination (17-19,22). This direction appears to be inverted only at the tectal midline in which the median ventricular formation $(17,18)$ - a specialized type of radial glia - may provide a site of selective entrance from the pia and support for microglial migration (96).

Our thymidine labeling studies are not directly comparable to the classical study of Imamoto and Leblond (97) since we have used a chronological series, employed only single injections of $\left[{ }^{3} \mathrm{H}\right]-\mathrm{T}$ and sacrificed each animal two hours later whereas those authors used multiple injections, all given on a single postnatal day and multiple survivals, with minimal survival of one day. Nevertheless, our results were similar to theirs concerning ameboid cells which were $\left[{ }^{3} \mathrm{H}\right]-\mathrm{T} /$ lectin labeled in our study (Figure 5). However, pericytes which also carry the galactosyl groups recognized by the Griffonia B4 lectin were $\left[{ }^{3} \mathrm{H}\right]-\mathrm{T}+$ at ages up to eye opening, when $70 \%$ of the developmental period has elapsed, but were $\left[{ }^{3} \mathrm{H}\right]-\mathrm{T}$ - in the study of Imamoto and Leblond (97) in 5-6-day-old rats (at about $40 \%$ of the developmental period). It is interesting to note that Korr (32) reported proliferation of pericytes up to the 20th postnatal day in a short survival study in the mouse, i.e., near the end of the developmental period. Thus, a discrepancy between long and short survival results might signify that pericytes also contribute to parenchymal microglia.

Griffonia B4 isolectin is a constant marker of the macrophage/microglia lineage and, thus, a differentiated microglial cell has to be defined in terms of the complexity of its processes. Fairly ramified microglia are found in the opossum superior colliculus soon after the appearance of roundish and ameboid microglia and include a low proportion of cells with $\left[{ }^{3} \mathrm{H}\right]-\mathrm{T} / \mathrm{lectin}-\mathrm{labeled}$ cells. Furthermore, highly ramified microglia such as those found near the time of eye opening also include a small population of cells show- 
ing plasmalemmal lectin labeling and nuclear $\left[{ }^{3} \mathrm{H}\right]$-T labeling (Figure 5).

Proliferation of ramified microglia was not observed by Imamoto and Leblond (97) but that result was not entirely unexpected since ramified cells form the bulk of microglia in rats by the second postnatal week and proliferation of microglia/pericytes was reported by Korr (32) up to postnatal day 20. Moreover, in the adult mouse $\left[{ }^{3} \mathrm{H}\right]-\mathrm{T}$ labeling has been detected in ramified microglia unequivocally identified by the F4/80 antibody in both short and long survivals after $\left[{ }^{3} \mathrm{H}\right]-\mathrm{T}$ injection (98).

In view of the abundant evidence in favor of microglial origin from bone marrow cells (reviewed in Ref. 99, but see Ref. 88) and the report of a small proportion of DNA-synthesizing monocytes in the circulation of adult rodents (100), it may be asked whether both ameboid and complexly ramified $\left[{ }^{3} \mathrm{H}\right]-\mathrm{T}+$ microglia took up label as circulating monocytes and arrived recently to their position in

Figure 5 - Proliferation of ameboid and ramified microglia. High power photomicrographs of coronal sections passing through the midbrain tectum of pouch young opossums that received a single intraperitoneal $\left[{ }^{3} \mathrm{H}\right]-\mathrm{T}$ injection $(10 \mu \mathrm{Ci} / \mathrm{g}$ body weight) at P24 (A and B) or P59 (C and D) and were killed $2 \mathrm{~h}$ later. Sections were incubated with an HRP conjugate of the BS1/B4 Griffonia simplicifolia isolectin (Sigma). $A$ and $C$, Focus on the histochemical reaction; $B$ and $D$, focus on the radioautographic emulsion ( $C$ and $D$ modified from Ref. 22; courtesy of SBPC). Magnification bar $=10 \mu \mathrm{m}$.
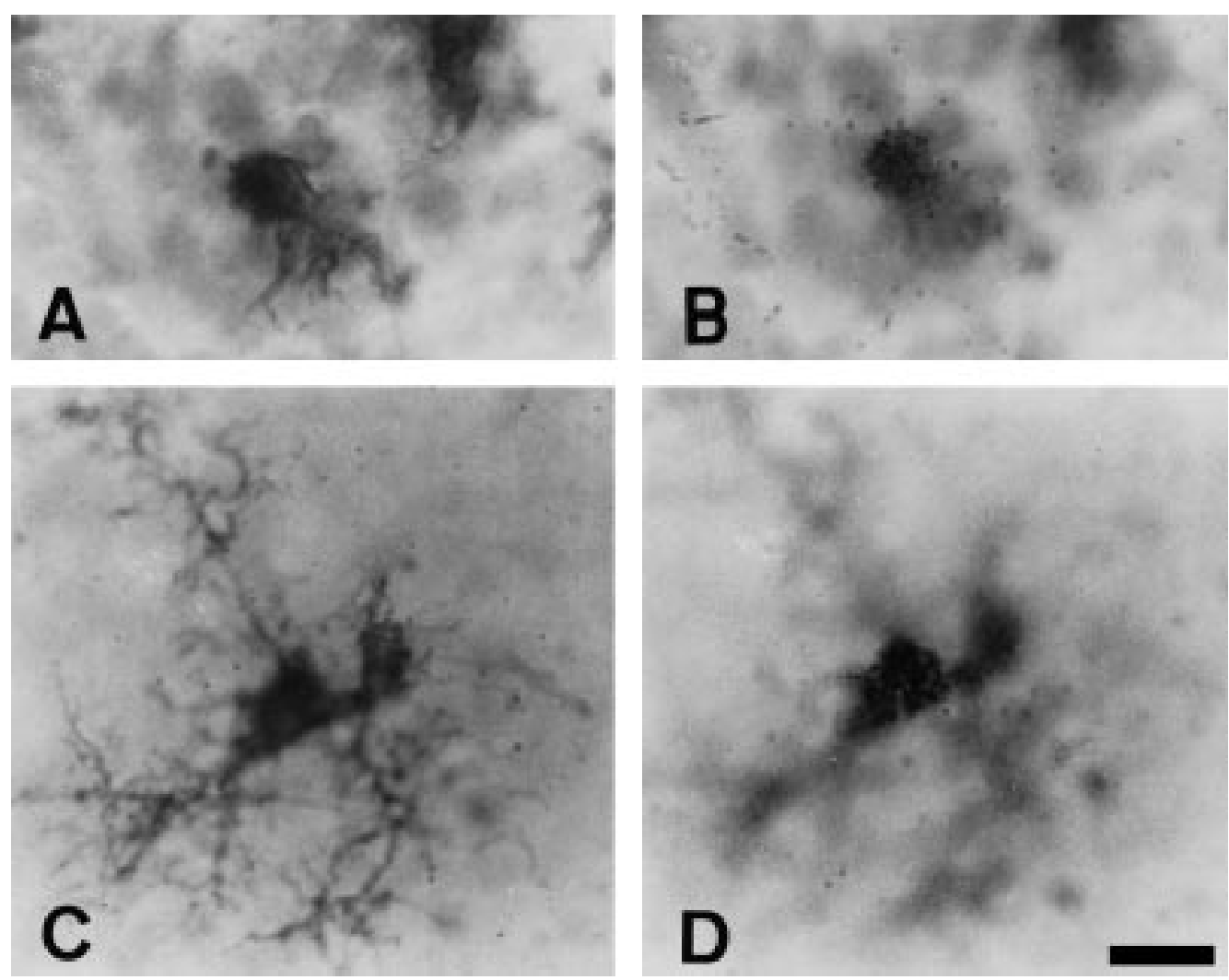

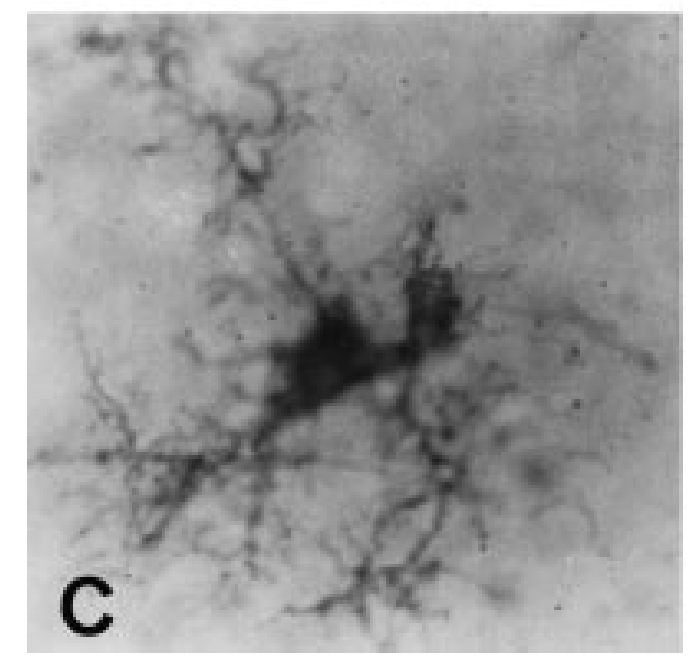

the collicular parenchyma. That may be plausible for ameboid cells since there is evidence for concomitant mitosis and migration of these cells through the retinal optic fiber layer (101). However, it seems unlikely that a putative exogenous cell may go through the sequence of taking up $\left[{ }^{3} \mathrm{H}\right]-\mathrm{T}$, entering and migrating through the brain parenchyma, and developing elaborate processes within the $2 \mathrm{~h}$ from $\left[{ }^{3} \mathrm{H}\right]-\mathrm{T}$ injection to sacrifice. There are obviously no data on individual cells since even relatively complex in vitro systems such as organotypic slice cultures involve a certain degree of neuronal death and microglial rounding up and "activation". However, recent work with organotypic hippocampal slice cultures have shown originally ramified microglia (zero days in vitro), that become roundish within the subsequent three days in vitro and gradually return to a ramified morphology after at least six days in vitro (102). This result may not be representative of the normal developing brain but 
suggests that ramification may take closer to $20 \mathrm{~h}$ rather than to $2 \mathrm{~h}$.

At this point, the most pertinent question is whether $\left[{ }^{3} \mathrm{H}\right]-\mathrm{T}$ labeling of differentiated cells, i.e., CNPase-expressing oligodendroglia and ramified microglia, is of significance since DNA-synthesizing cells are few in number (both cases) or occur within a narrow time window during development of the brain stem (oligodendroglia). Furthermore, Korr (32) has estimated that as many as $17 \%$ of all DNA-synthesizing cells of the brain fail to divide or die or division occurs but daughter cells die. However, no heroic conditions such as continuous infusion of $\left[{ }^{3} \mathrm{H}\right]-\mathrm{T}$ have been used to maximize the detection of DNA-synthesizing cells in our studies, and thus we believe that proliferation of small fractions of differentiated oligodendroglia and microglia is of actual or potential functional importance.

\section{Conclusions}

A few conclusions can be drawn from the combination of radioautographic studies of proliferation and immunohistochemical or lectin-binding studies of oligodendroglial and microglial cells in the opossum brain stem. First, the developing brain stem is regionally heterogeneous in terms of the proliferation capacity of oligodendrocytes that express the ensheathing protein 2'3'-cyclic nucleotide 3'-phosphodiesterase. This capacity is virtually restricted to interfascicular cells of the lower brain stem. Second, regional heterogeneity of the proliferative ability of CNPase+ oligodendrocytes is not necessarily related to the duration of expression of this ensheathing protein in oligodendroglial cell bodies. Third, both ameboid and highly ramified microglia in the developing brain stem are able to proliferate.

\section{Acknowledgments}

We thank Dr. Peter Braun for donating the affinity-purified anti-CNPase antibody, Sergio L. Carvalho for technical assistance, Alessandra Santos-Silva and Silvana S. Gomes for help in early stages of this work, and Paulo C. Coutinho for animal care. The valuable assistance of the Laboratório Nacional de Computação Científica with electronic communication is gratefully acknowledged.

\section{References}

1. Smart I (1961). The subependymal layer of the mouse brain and its cell production as shown by radioautography after thymidine $\mathrm{H}^{3}$ injection. Journal of Comparative Neurology, 116: 325-347.

2. Mori S \& Leblond CP (1970). Electron microscopic identification of three classes of oligodendrocytes and a preliminary study of their proliferative activity in the corpus callosum of young rats. Journal of Comparative Neurology, 139: 1-30.

3. Vaughn JE \& Peters A (1971). The morphology and development of neuroglial cells. In: Pease DC (Editor), Cellular Aspects of Neural Growth and Differentiation. University of California Press, Los Angeles, 103-140.
4. Privat A \& Leblond CP (1972). The subependymal layer and neighboring region in the brain of the young rat. Journal of Comparative Neurology, 146: 277-301.

5. Paterson JA, Privat A, Ling EA \& Leblond CP (1973). Investigation of glial cells in semithin sections. III - Transformation of subependymal cells into glial cells as shown by radioautography after $3 \mathrm{H}$-thymidine injection into the lateral ventricle of the brain of young rats. Journal of Comparative Neurology, 149: 83-102.

6. Cooper ML \& Rakic P (1981). Neurogenetic gradients in the superior and the inferior colliculi of the Rhesus monkey. Journal of Comparative Neurology, 202: 309-334.
7. Cavalcante LA, Rocha-Miranda CE \& Linden $R$ (1984). Observations on neurogenesis of the superior colliculus and pretectum in the opossum. Developmental Brain Research, 13: 241-249.

8. Kendler A \& Golden JA (1996). Progenitor cell proliferation outside the ventricular and subventricular zones during human brain development. Journal of Neuropathology and Experimental Neurology, 55: 1253-1258.

9. Kishi K (1987). Golgi studies on the development of granule cells of the rat olfactory bulb with reference to the migration in the subependymal layer. Journal of Comparative Neurology, 258: 112-124. 
10. Kishi K, Peng JY, Kakuta S, Murakami K, Kuroda M, Yokota S, Hayakawa S, Kuge T \& Asayama T (1990). Migration of bipolar subependymal cells, precursors of the granule cells of the rat olfactory bulb, with reference to the arrangement of the radial glial fibers. Archives of Histology and $\mathrm{Cy}$ tology, 53: 219-226.

11. Luskin MB (1993). Restricted proliferation and migration of postnatally generated neurons derived from the forebrain subventricular zone. Neuron, 11: 173-189.

12. Lois C \& Alvarez-Buylla A (1994). Longdistance neuronal migration in the adult mammalian brain. Science, 264: 11451148.

13. Morshead CM \& van der Kooy D (1992). Postmitotic death is the fate of constitutively proliferating cells in the subependymal layer of the adult mouse brain. Journal of Neuroscience, 12: 249-256.

14. Wang E (1989). Statin, a nonproliferationspecific protein, is associated with the nuclear envelope and is heterogeneously distributed in cells bearing quiescent state. Journal of Cell Physiology, 140: 418426.

15. Kurki $P$, Vanderlaan $M$, Dolbeare $F$, Gray J \& Tan EM (1986). Expression of proliferating cell nuclear antigen (PCNA)/cyclin during the cell cycle. Experimental Cell Research, 166: 209-219.

16. Schipper HM \& Wang E (1990). Expression of statin, a non-proliferation-dependent nuclear protein, in the postnatal rat brain: evidence for substantial retention of neuroglial proliferative capacity with aging. Brain Research, 528: 250-258.

17. Cavalcante LA \& Barradas PC (1995). Astroglial differentiation and correlated neuronal changes in the opossum superior colliculus. In: Vernadakis A \& Roots B (Editors), Neuron-Glia Interrelations during Phylogeny. Humana Press, Totowa, NJ, 79-101.

18. Barradas PC, Cavalcante LA, MendezOtero R \& Vieira AM (1989). Astroglial differentiation in the opossum superior colliculus. Glia, 2: 103-111.

19. Cavalcante LA, Barradas PC \& Martinez AMB (1991). Patterns of myelination in the opossum superior colliculus with additional reference to the optic tract. Anatomy and Embryology, 183: 273-285.

20. Barradas PC, Gomes SS, Carvalho SL \& Cavalcante LA (1994). Differentiation of oligodendroglia in the opossum's brainstem and cerebellum. Society of Neuroscience Abstracts, 20: 692.
21. Barradas PC, Gomes SS \& Cavalcante LA (1995). CNPase expression in the developing opossum brainstem and cerebellum. NeuroReport, 6: 289-292.

22. Cavalcante LA, Santoro GF, Barradas PC, Santos-Silva A \& Carvalho SL (1995). Lectin histochemistry of microglia in superior colliculus of the developing opossum. Ciência e Cultura, 47: 240-245.

23. Allodi S, Cavalcante LA, Hokoç JN \& Bernardes RF (1992). Genesis of neurons of the retinal ganglion cell layer in the opossum. Anatomy and Embryology, 185: 489-499.

24. Robinson SR \& Dreher B (1990). The visual pathways of eutherian mammals and marsupials develop according to a common timetable. Brain, Behavior and EvoIution, 36: 177-195.

25. Reynolds HC (1952). Studies of reproduction in the opossum. University of California Publications in Zoology, 52: 233-284.

26. Ashwell KS, Waite PME \& Marotte L (1996). Ontogeny of the projection tracts and commissural fibres in the forebrain of the tammar wallaby (Macropus eugenii): Timing in comparison with other mammals. Brain, Behavior and Evolution, 47: 8-22.

27. LeVine SM \& Goldman JE (1988). Spatial and temporal patterns of oligodendrocyte development in rat forebrain. Journal of Comparative Neurology, 277: 441-455.

28. Hardy R \& Reynolds R (1991). Proliferation and differentiation potential of rat forebrain oligodendroglial progenitors both in vitro and in vivo. Development, 111: 1061-1080.

29. Wolswijk G (1995). Strongly GD3+ cells in the developing and adult rat cerebellum belong to the microglial lineage rather than to the oligodendrocyte lineage. Glia, 13: $13-26$.

30. Ghandour MA, Langley OK, Vincendon G, Gombos G, Filippi D, Limozin N, Dalmasso C \& Laurent G (1980). Immunocytochemical and immunohistochemical study of carbonic anhydrase II in adult rat cerebellum: A marker for oligodendrocytes. Neuroscience, 5: 559-571.

31. Nogradi A (1993). Differential expression of carbonic anhydrase isozymes in microglial cell types. Glia, 8: 133-142.

32. Korr H (1986). Proliferation and cell cycle parameters of astrocytes. In: Fedoroff $S$ \& Vernadakis A (Editors), Astrocytes. Cell Biology and Pathology of Astrocytes. Vol. 3. Academic Press, New York, 77-127.

33. Hardonk MJ \& Harms G (1990). The use of 5'-bromodeoxyuridine in the study of cell proliferation. Acta Histochemica, 39 (Suppl): 99-108.
34. Celis JE, Madsen P, Celis A, Nielsen HV \& Gesser B (1987). Cyclin (PCNA, auxiliary protein of DNA polymerase delta) is a central component of the pathway(s) leading to DNA replication and cell division. FEBS Letters, 220: 1-7.

35. Prelich G, Tan C, Kostura M, Mathews $M B$, So AG, Downey KM \& Stillman B (1987). Functional identity of proliferating cell nuclear antigen and a DNA polymerase-delta auxiliary protein. Nature, 326: 517-520.

36. Shapiro HM (1989). Flow cytometry of DNA content and other indicators of proliferative activity. Archives of Pathology and Laboratory Medicine, 113: 591-597.

37. Tapscott SJ, Lassar AB, Davis RL \& Weintraub H (1989). 5-Bromo-2'-deoxyuridine blocks myogenesis by extinguishing expression of MyoD1. Science, 245: 532536.

38. Novakowski RS, Lewin SB \& Miller MW (1989). Bromodeoxyuridine immunohistochemical determination of the lengths of the cell cycle and the DNA-synthetic phase for an anatomically defined population. Journal of Neurocytology, 18: 311318.

39. Blenkinsopp WK (1967). Effect of tritiated thymidine on cell proliferation. Journal of Cell Science, 2: 305-308.

40. Fliedner TM, Hass RJ, Stehle H \& Adams A (1968). Complete labeling of all cell nuclei in newborn rats with $\mathrm{H}^{3}$-thymidine. $\mathrm{A}$ tool for the evaluation of rapidly and slowly proliferating cell systems. Laboratory Investigation, 16: 249-259.

41. Tsue TT, Watling DL, Weisleder P, Coltrera MD \& Rubel EW (1994). Identification of hair cell progenitors and intermitotic migration of their nuclei in the normal and regenerating avian inner ear. Journal of Neuroscience, 14: 140-152.

42. del Rio Hortega P (1942). La neuroglia normal - Conceptos de angiogliona y neurogliona. Archivos de Histologia Normal y Patologica, 1: 5-72.

43. Raff MC, Mirsky R, Fields KL, Lisak RP, Dorfman SH, Silderberg DH, Gregson NA, Leibowitz S \& Kennedy MC (1978). Galactocerebroside is a specific cell-surface antigenic marker for oligodendrocytes in culture. Nature, 274: 813-816.

44. Sternberger NH, Itoyama $\mathrm{Y}$, Kies MW \& Webster H de F (1978). Myelin basic protein demonstrated immunocytochemically in oligodendroglia prior to myelin sheath formation. Proceedings of the National Academy of Sciences, USA, 76: 2521-2524. 
45. Sommer I \& Schachner M (1981). Monoclonal antibodies (O1 to O4) to oligodendrocyte cell surfaces: an immunocytochemical study in the central nervous system. Developmental Biology, 83: 311327.

46. Schachner M, Kim SK \& Zehnle R (1981). Developmental expression in central and peripheral nervous system of oligodendrocyte cell surface antigens ( $O$ antigens) recognized by monoclonal antibodies. Developmental Biology, 83: 328-338.

47. Lent R \& Jhaveri S (1991). Myelination of the cerebral commissures of the hamster as revealed by a monoclonal antibody specific for oligodendrocytes. Developmental Brain Research, 66: 193-201.

48. Jhaveri S, Erzurumlu RS, Friedman B \& Schneider G (1992). Oligodendrocytes and myelin formation along the optic tract of the developing hamster: An immunohistochemical study using the Rip antibody. Glia, 6: 138-148.

49. Braun PE, Sandillon F, Edwards A, Mathieu JM \& Privat A (1988). Immunocytochemical localization by electron microscopy of 2'3'-cyclic nucleotide 3' phosphodiesterase in developing oligodendrocytes of normal and mutant brain. Journal of Neuroscience, 8: 3057-3066.

50. Reynolds R \& Wilkin GP (1988). Development of macroglial cells in rat cerebellum. II. An in situ immunohistochemical study of oligodendroglial precursors to mature myelinating cell. Development, 102: 409425.

51. Amur-Umarjee SG, Dasu RG \& Campagnoni AT (1990). Temporal expression of myelin specific components in neonatal mouse brain cultures: Evidence that 2'3'-cyclic nucleotide 3' phosphodiesterase appears prior to galactocerebroside. Developmental Neuroscience, 12: 251-262.

52. Braun PE, Bambrick LL, Edwards AM \& Bernier L (1990). 2'3'-cyclic nucleotide 3'phosphodiesterase has characteristics of cytoskeletal proteins. A hypothesis for its function. Annals of the New York Academy of Sciences, 605: 55-65.

53. Dyer CA \& Benjamins JA (1989). Organization of oligodendroglial membrane sheaths. I. Association of MBP and CNP with cytoskeleton. Journal of Neuroscience Research, 24: 201-211.

54. Brophy PJ (1992). Interactions of lipids with proteins of myelin and its associated cytoskeleton. In: Martenson RE (Editor), Myelin: Biology and Chemistry. CRC Press, Boca Raton, FL, 197-212.
55. Scherer SS, Braun PE, Grinspan J, Collarini E, Wang D-Y \& Kamholz J (1994). Differential regulation of the 2'-3'-cyclic nucleotide 3'-phosphodiesterase gene during oligodendrocyte development. Neuron, 12: 1363-1375.

56. Pringle NP \& Richardson WD (1993). A singularity of PDGF $\alpha$-receptor in the dorsoventral axis of the neural tube may define the origin of the oligodendrocyte lineage. Development, 117: 525-533.

57. Yu W-P, Collarini EJ, Pringle NP \& Richardson WD (1994). Embryonic expression of myelin genes: evidence for a focal source of oligodendrocyte precursors in the ventricular zone of the neural tube. Neuron, 12: 1353-1362.

58. Timsit $S$, Martinez $S$, Allinquant $B$, Peyron $F$, Puelles L \& Zalc B (1995). Oligodendrocytes originate in a restricted zone of the embryonic ventral neural tube defined by DM-20 mRNA expression. Journal of $\mathrm{Neu}$ roscience, 15: 1012-1024.

59. Raff MC (1989). Glial cell diversification in the rat optic nerve. Science, 243: 14501455.

60. Monge $M$, Kadiiski $D$, Jacque $C M$ \& Zalc B (1986). Oligodendroglial expression and deposition of four major myelin constituents in the myelin sheath during development: An in vivo study. Developmental Neuroscience, 8: 222-235.

61. Coffey JC \& McDermott KW (1997). The regional distribution of myelin oligodendrocyte glycoprotein (MOG) in the developing rat CNS: an in vivo immunohistochemical study. Journal of Neurocytology, 26: 149-161.

62. Holz A, Schaeren-Wiemers N, Schaefer C, Pott U, Colello RJ \& Schwab M (1996). Molecular and developmental characterization of novel cDNAs of the myelin-associated/oligodendrocytic basic protein. Journal of Neuroscience, 16: 467-477.

63. Matus A \& Mughal S (1975). Immunohistochemical localization of S-100 protein in brain. Nature, 258: 746-748.

64. Linser PJ \& Perkins M (1987). Gliogenesis in the embryonic avian optic tectum: neuronal-glial interactions influence astroglial phenotype maturation. Developmental Brain Research, 31: 277-290.

65. Bansal R, Warrington AE, Gard AL, Ranscht B \& Pfeiffer SE (1989). Multiple and novel specificities of monoclonal antibodies $\mathrm{O1}, \mathrm{O} 4$ and R-mAb used in the analysis of OL development. Journal of Neuroscience Research, 24: 548-557.
66. Skoff RB, Ghandour MS \& Knapp PE (1994). Postmitotic oligodendrocytes generated during postnatal cerebral development are derived from proliferation of immature oligodendrocytes. Glia, 12: 24-34

67. Murabe $Y \&$ Sano $Y$ (1982). Morphological studies on neuroglia. VI. Postnatal development of microglial cells. Cell and Tissue Research, 225: 469-485.

68. Fujimoto E, Miki A \& Mizoguti H (1989). Histochemical study of the differentiation of microglial cells in the developing human cerebral hemispheres. Journal of Anatomy, 166: 253-264.

69. Fujimoto E, Miki A \& Mizoguti H (1987). Histochemical studies of the differentiation of microglial cells in the cerebral hemispheres of chick embryos and chicks. Histochemistry, 87: 209-216.

70. Castellano B, González B, Dalmau I \& Vela JM (1991). Identification and distribution of microglial cells in the cerebral cortex of the lizard: A histochemical study. Journal of Comparative Neurology, 311: 434-444.

71. Streit WJ \& Kreutzberg GW (1987). Lectin binding by resting and reactive microglia. Journal of Neurocytology, 16: 249-260.

72. Ashwell K (1990). Microglia and cell death in the developing mouse cerebellum. Developmental Brain Research, 55: 219-230.

73. Acarin L, Vela JM, González B \& Castellano B (1994). Demonstration of poly- $\mathrm{N}$-acetyl lactosamine residues in ameboid and ramified microglia cells in rat brain by tomato lectin binding. Journal of Histochemistry and Cytochemistry, 42: 1033-1041.

74. Dowding AJ, Maggs A \& Scholes J (1991) Diversity amongst the microglia in growing and regenerating fish CNS: Immunohistochemical characterization using FL.1, an anti-macrophage monoclonal antibody. Glia, 4: 345-364.

75. Goodbrand IA \& Gaze RM (1991). Microglia in tadpoles of Xenopus laevis: Normal distribution and the response to optic nerve injury. Anatomy and Embryology, 184: 71-82.

76. Perry VH, Hume DA \& Gordon S (1985). Immunohistochemical localization of macrophages and microglia in the adult and developing mouse brain. Neuroscience, 15: 313-326.

77. Imamura K, Ito M, Suzumura A, Asai J \& Takahashi A (1990). Generation and characterization of monoclonal antibodies against rat microglia and ontogenic distribution of positive cells. Laboratory Investigation, 63: 853-861. 
78. Ling EA, Kaur C, Yick TI \& Wong WC (1990). Immunocytochemical localization of CR3 complement receptors with OX42 in ameboid microglia in postnatal rats. Anatomy and Embryology, 182: 481-486.

79. Gehrmann J \& Kreutzberg GW (1991). Characterisation of two new monoclonal antibodies directed against rat microglia. Journal of Comparative Neurology, 313: 409-430.

80. Chugani DC, Kedersha NL \& Rome LH (1991). Vault immunofluorescence in the brain: new insights regarding the origin of the microglia. Journal of Neuroscience, 11: 256-268.

81. Penfold PL, Madigan MC \& Provis JM (1991). Antibodies to human leucocyte antigens indicate subpopulations of $\mathrm{mi}$ croglia in human retina. Visual Neuroscience, 7: 383-388.

82. Cuadros MA, Moujahid A, Martín-Partido G \& Navascués J (1992). Microglia in the mature and developing quail brain as revealed by a monoclonal antibody recognizing hemopoietic cells. Neuroscience Letters, 148: 11-14.

83. Austyn JM \& Gordon S (1981). F4/80: a monoclonal antibody directed specifically against the mouse macrophage. European Journal of Immunology, 10: 805811.

84. Pardanaud L, Altmann C, Kitos $\mathrm{P}$, Dieterlen-Lièvre F \& Buck C (1987). Vasculogenesis in the early quail blastodisc as studied with a monoclonal antibody recognizing endothelial cells. Development, 100: 339-349.

85. Cuadros MA, Martin C, Coltey P, Almendros A \& Navascués J (1993). First appearance, distribution and origin of macrophages in the early development of the avian central nervous system. Journal of Comparative Neurology, 330 : 113-129.
86. Cuadros MA, Moujahid A, Quesada A \& Navascués J (1994). Development of microglia in the quail optic tectum. Journal of Comparative Neurology, 348: 207-224.

87. Navascués J, Moujahid A, Almendros A, Marín-Teva JL \& Cuadros MA (1995). Origin of microglia in the quail retina: Central-to-peripheral and vitreal-to-scleral migration of microglial precursors during development. Journal of Comparative Neurology, 354: 209-228.

88. Fedoroff S (1995). Development of microglia. In: Kettenman H \& Ransom BR (Editors), Neuroglia. Oxford University Press, New York \& Oxford, 162-181.

89. Meinecke DL \& de F Webster H (1984). Fine structure of dividing astroglia and oligodendroglia during myelin formation in the developing mouse spinal cord. Journal of Comparative Neurology, 222: 47-55.

90. Skoff RP, Price DL \& Stocks A (1976). Electron microscopic autoradiographic studies of gliogenesis in rat optic nerve. I. Cell proliferation. Journal of Comparative Neurology, 169: 291-312.

91. Sturrock RR (1981). Electron microscopic evidence for mitotic division of oligodendrocytes. Journal of Anatomy, 132: 429-432.

92. Sturrock RR (1976). Light microscopic identification of immature glial cells in semithin sections of the developing mouse corpus callosum. Journal of Anatomy, 122: 521-537.

93. Gard AL \& Pfeiffer SE (1990). Two proliferative stages of the oligodendrocyte lineage (A2B5+O4- and O4+GalC-) under different mitogenic control. Neuron, 5: 615-625.

94. Timsit SG, Bally-Cuif L, Colman DR \& Zalc $B$ (1992). DM-20 mRNA is expressed during early development of the nervous system of the mouse. Journal of Neurochemistry, 58: 1172-1175.
95. Barradas PC, Gomes SS \& Cavalcante LA (1997). Heterogeneous patterns of oligodendroglial differentiation in the forebrain of the opossum Didelphis marsupialis. Journal of Neurocytology (in press).

96. Cavalcante LA, Garcia-Abreu J, Moura Neto V, Silva LCF \& Barradas PC (1996). Heterogeneity of median and lateral midbrain radial glia and astrocytes. Revista Brasileira de Biologia, 56 (Suppl 1): 3352.

97. Imamoto K \& Leblond CP (1978). Radioautographic investigation of gliogenesis in the corpus callosum of young rats. II. Origin of microglial cells. Journal of Comparative Neurology, 180: 139-164.

98. Lawson LJ, Perry VH \& Gordon S (1992). Turnover of resident microglia in the normal adult mouse brain. Neuroscience, 48 : 405-415.

99. Ling EA \& Wong WC (1993). The origin and nature of ramified and ameboid microglia: a historical review and current concepts. Glia, 7: 9-19.

100. Van Furth R, Diesselhoff-Den Dulk MMC, Sluiter W \& Van Dissel JT (1985). New perspectives on the kinetics of mononuclear phagocytes. In: Van Furth R (Editor), Mononuclear Phagocytes: Characteristics, Physiology and Function. Martinus Nijhoff Publications, Dordrecht, The Netherlands, 201-210.

101. Marín-Teva JL, Almendros A, Cuadros MA, Calvente R \& Navascués J (1996). Proliferation of actively migrating ameboid microglia in the developing quail retina. European Journal of Neuroscience, Suppl 9: 159 (Abstract).

102. Hailer NP, Järhult JD \& Nitsch R (1996). Resting microglia in vitro: Analysis of morphology and adhesion molecule expression in organotypic hippocampal slice culture. Glia, 18: 319-331. 